\title{
THE PLANT LOCATION DECISION IN MULTINATIONAL MANUFACTURING FIRMS: AN EMPIRICAL ANALYSIS OF INTERNATIONAL BUSINESS AND MANUFACTURING STRATEGY PERSPECTIVES
}

\author{
THOMAS H. BRUSH, CATHERINE A. MARITAN, AND ANEEL K ARNANI \\ Krannert Graduate School of Management, Purdue University, West Lafayette, \\ Indiana 47907, USA \\ Krannert Graduate School of Management, Purdue University, West Lafayette, \\ Indiana 47907, USA \\ School of Business Administration, University of Michigan, Ann Arbor, \\ Michigan 48104, USA
}

\begin{abstract}
The paper combines perspectives from international business and manufacturing to examine multinational plant location decisions. The location choice in manufacturing is between integrated and independent plants, while the international choice is between a foreign and domestic plant relative to their headquarters' country. The study empirically investigates whether these choices have different plant location determinants using data from a survey of plant managers of large, multinational firms. We find more evidence that the manufacturing choices benefit from consideration of international business issues than vice versa. However, managers rank determinants associated with manufacturing strategy considerably higher than those associated with international business.

(PLANT LOCATION; INTERNATIONAL MANAGEMENT; MANUFACTURING STRATEGY; PLANT NETWORKS)
\end{abstract}

\section{Introduction}

Popular management articles assert that a variety of both manufacturing strategy and international factors determine plant location decisions. One recent article argues that new production systems and technologies are forcing firms to use new criteria for locating a network of smaller, flexible, interdependent plants. Regional infrastructure and local skills are thought to be more important than in the past. In addition, the emergence of more sophisticated markets overseas now means that lead users are no longer concentrated in a few markets, and feedback must often be solicited from them both for use in these local plants and for the rest of the network of plants (MacCormack, Newman, and Rosenfeld 1994). Another view emphasizes the need to consider plant location as a means of developing key capabilities for the firm and stresses the integration of the plant with key functions and activities of the firm (Bartmess and Cerny 1993; Bartmess 1994). But exactly how do managers weigh these factors in deciding where to locate a plant?

Traditional plant location criteria emphasize cost-based variables such as scale economies, transportation cost, and factor cost advantages, as well as plant mission within the 
business unit in a domestic context (Schmenner 1982). More recently, some conceptual articles speculate on manufacturing issues when considering how the determinants of plant location may differ in an international context (Ferdows 1989), but typically international business focuses on variation in factor costs and government policies associated with different markets and locations (Dunning 1988, 1993). This paper proposes a framework for systematically investigating the plant location choice that incorporates both international business and manufacturing strategy literature. The framework allows us to combine and contrast these two perspectives to investigate the multinational plant location decision. Both perspectives together allow us to investigate the broader problem of the management of multinational firms and their networks of plants that are integrated and coordinated across international borders (Prahalad and Doz 1987; Kogut 1985, 1989). By focusing on a particular managerial decision, the plant location decision, we also contrast the relative applicability of underlying theories.

We categorize plants along two dimensions: whether the plant is domestic or foreign relative to the headquarters country, and whether the plant is independent or integrated with other plants in the firm (see Table 1). We perform a three-stage comparison of the determinants of plant location for the four categories of plants. First, we compare the determinants of plant location for integrated plants to those for independent plants. Likewise, we compare the determinants of plant location for foreign plants to domestic plants. Second, we further examine these determinants of plant location for integrated and independent plants to determine whether they differ if the setting is domestic or foreign. Similarly, we also examine whether the determinants of plant location for foreign and domestic plants differ according to whether the plants are integrated or independent. Third, we examine whether the managers' ranking of the importance of determinants of plant location differs between the four basic types as well as whether they are changing over time in a manner that is consistent with the popular literature on changes in global manufacturing.

\section{Literature Review}

\section{Manufacturing Strategy}

Schmenner $(1979,1982)$ introduced the notion of explicitly considering plant strategy in the plant location decision. He argued that the role of the plant to be located and its relationship to other plants in a multiple plant network are important considerations that could lead to a different location choice than would be made if only traditional economic factors were considered. The need for integration with other plants concerning material flows, knowledge transfers, etc. could alter the location choice for plants relative to standalone independent plants. Multiple plant manufacturing should be understood as a system, and plant characteristics need to be understood relative to that system. Schmenner's work

TABLE 1

Typology of Plant Strategies Based on Dimensions of Integration and Location Relative to Parent Headquarters

\begin{tabular}{|c|c|c|c|}
\hline & & \multicolumn{2}{|c|}{ Location Relative to Parent Headquarters } \\
\hline & & Domestic Plant & Foreign Plant \\
\hline \multirow{4}{*}{$\begin{array}{l}\text { Degree of } \\
\text { integration }\end{array}$} & \multirow{3}{*}{ Integrated plant } & 1 & 2 \\
\hline & & Integrated domestic & Integrated foreign \\
\hline & & 3 & 4 \\
\hline & Independent plant & Independent domestic & Independent foreign \\
\hline
\end{tabular}


provides insight into how different plant strategies require integration to different degrees and how this influences the plant location decision.

Schmenner's (1982) work, however, is limited to a domestic setting. Conceptual articles have addressed the challenges of coordinating a plant network and the ways in which these challenges may differ in an international context (Ferdows 1989; Flaherty 1986; Oliff, Arpan, and Dubois 1989). However, these articles do not apply the frameworks to specific plant decisions such as the location decision.

The manufacturing strategy literature clearly points to the importance of incorporating the relationship a plant has with other plants into the understanding of plant decisions such as the location decision.

\section{International Business}

The eclectic theory of international production (Dunning 1988, 1993) holds that advantages deriving from asset ownership (e.g., tangible assets, patents, technology, skills), location-bound endowments (e.g., input prices and quality, investment incentives, infrastructure, culture and trade barriers ), and internationalization of cross-border market transactions (e.g., minimization of transaction costs such as search and negotiation costs, uncertainty about the nature and value of inputs, and the opportunity to capture the economies of interdependent activities ) explain the propensity of firms to engage in foreign production.

The international management literature argues that multinational firms should pursue different strategies depending on characteristics of the markets and products involved. A widely used framework to examine the organizational demands of international management is the Integration-Responsiveness Grid (IR grid), with dimensions of Pressures for Global Integration and Pressures for Local Responsiveness (Prahalad and Doz 1987). This framework is useful for identifying the managerial demands that are necessary for businesses with different competitive priorities relative to their product markets. Pressures for local responsiveness include the need to customize products for local markets and tastes or to meet national regulations. Pressures for global integration include economies of scale in production or common tastes across markets for the product. These pressures could result in either export from a single plant or highly coordinated and interdependent production in combination with standardized final products. The plant location decision therefore should be influenced by the degree of interdependence and the need for coordination stemming from the firm's multinational strategy and its demands for the products made in a plant.

Kogut (1985, 1989) and Kogut and Kulatilaka (1994) focus on the advantages inherent in multinationality and explicitly model the value of flexibility under uncertainty. They argue that plant location considerations must incorporate the value of coordination of sourcing from multiple locations to reduce exchange rate risk exposure, to minimize taxes, to take advantage of government barriers or subsidies, and to create opportunities for cross-subsidization as a competitive weapon. Kogut and Kulatilaka (1994) mathematically formalize the option value of a multinational network, and Huchzermeier and Cohen (1996) extend this model to improve its tractability.

The international business literature clearly points to differences between countries and markets as factors to be considered in plant location decisions. These factors should be especially prominent in foreign, rather than domestic, location decisions.

\section{Determinants of Plant Location}

In the analysis reported in this paper, plants were classified as being domestic or foreign depending on whether or not they were located in the same country as the business unit headquarters. The degree of integration between the plant and the rest of the business unit 
was used to define whether a plant is integrated or independent. Integration was measured along two dimensions: (1) the degree of managerial coordination between the plant and the rest of the business unit, and (2) the presence of material flows between the plant and other plants in the business unit. We categorize plants as integrated plants when the plant has both a high level of material flows with other plants and a high level of managerial coordination.

In order to examine the plant location decision from the perspective of manufacturing strategy, we compare the location determinants for independent plants to those for integrated plants. To identify the effects of international business criteria, we want to compare how the determinants of plant location change when a company locates a plant in the same country as its headquarters versus locating in a foreign country. We also want to determine whether location determinants identified by manufacturing strategy, which emphasize coordination, vary between foreign and domestic plants, and in turn, whether international business determinants, which emphasize location specific advantages, vary between independent and integrated plants.

Plant location determinants can be grouped into three categories: Proximity to Other Network Nodes, Access to Factors of Production, and National and Regional Characteristics ( see Table 2).

\section{Proximity to Other Network Nodes: Plants, Customers, Suppliers, or Markets}

This group of determinants is most closely associated with a manufacturing perspective that recognizes relationships between a plant and other nodes in its network. These determinants are most useful for distinguishing between independent and integrated plants because they have different relationships with network nodes such as customers, suppliers, markets, and other plants.

\section{Access to Factors of Production}

Factor costs as location determinants are included within both manufacturing strategy and international business perspectives. While the opportunity to locate near critical factors of production may be important for all plants, the plant that is part of an integrated

TABLE 2

Groups, Factors, and Determinants of Plant Location

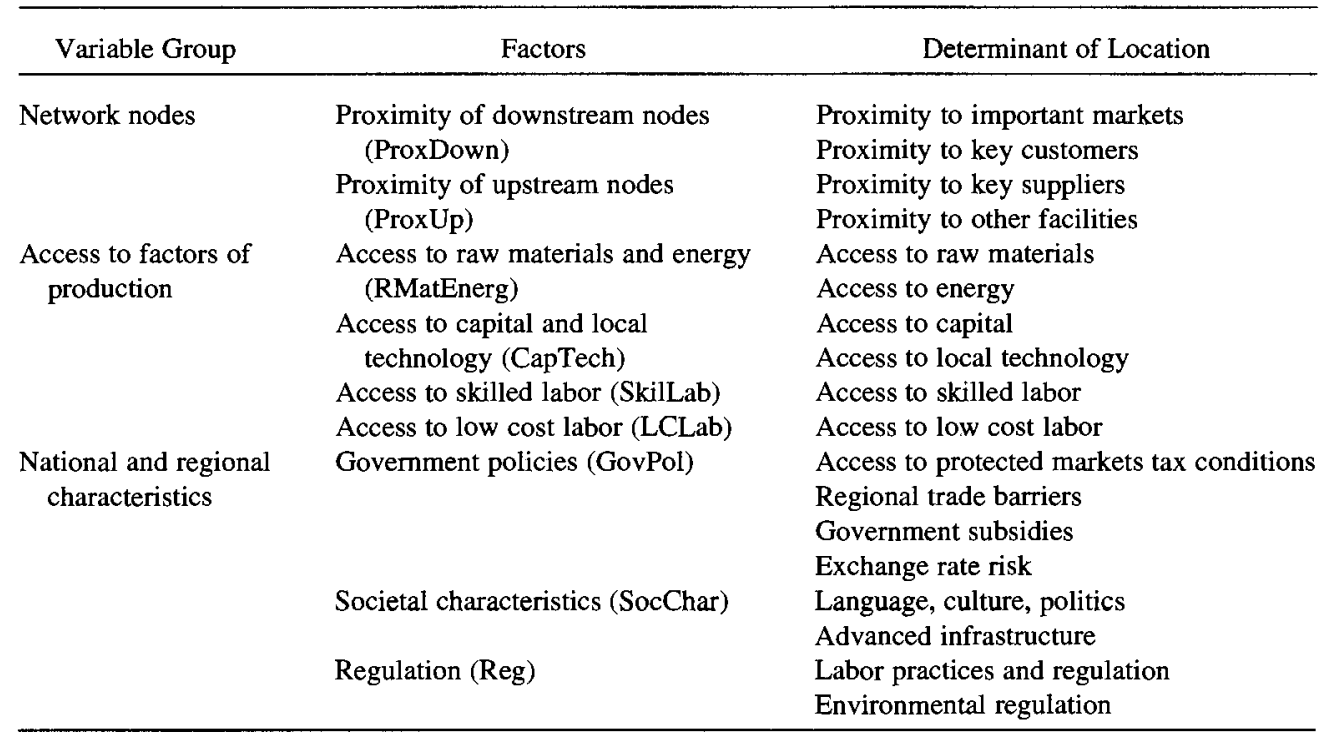


network of plants is more likely to be able to specialize in that part of the value chain that uses a critical factor intensively. This is consistent with what Schmenner $(1979,1982)$ called a process plant. It can thereby create a competitive advantage for the whole network through its location. Integrated plants, therefore, are more likely than independent plants to have access to factors of production as an important location determinant. Because variation in factor quality and cost is likely to be greater internationally than domestically, these determinants are also likely to be more important to locating foreign than domestic plants.

\section{National or Regional Characteristics}

This group of determinants is most closely associated with the international business literature and is more likely to be important for foreign plants than for domestic plants.

\section{Research Design}

\section{Data and Sample Description}

The data used in this analysis is from the Global Manufacturing Network Survey conducted by Professors Brian Talbot and Aneel Karnani of the Graduate School of Business Administration at the University of Michigan. The purpose of this survey was to assemble a comprehensive database containing a variety of data regarding the configuration and operation of international manufacturing plant networks. The survey was administered in 1991 to plant managers in 31 countries representing 73 large multinational companies whose headquarters are located in the United States, Europe, and Japan. Appendix 1 contains a list of the firms and the SIC codes of the business units and plants that participated. All firms involved in the survey had sent managers to the Global Leadership Executive Management Program at University of Michigan and thereby demonstrated an interest in and concern for education on management of international manufacturing enterprises. Managers that attended this program returned to their companies and distributed the survey to plant managers in their companies. The response rate was exceptionally high (above 90\%) for this reason. We received 209 responses; due to missing responses, this number was reduced to 167 observations for the data reflecting the actual location decision and 162 observations for the data reflecting whether the location decision was made now.

The survey was sent to plant managers with the rationale that these managers would be actively involved in the decisions involving capacity expansions through either new plants or expansions of old plants. We also checked how recently decisions involving plant expansions or a new plant had been made for the plant manager's plant as a means of assessing the likely validity of plant manager responses. We found that $48.8 \%$ of these plants had either capacity expansion or new construction in the last 5 years.

\section{Variables}

We classify plants as integrated or independent based on the degree of coordination and the presence of material flows. To determine the degree of coordination, an index is created based on responses to Question 4 in Appendix 2. The items in this question measure coordination between the plant and the business unit headquarters, other plants, and research and development (R\&D) facilities, much in the same way as Ferdows (1989) suggests. The coordination index is the sum of the responses to all the items in Question 4. If the value of the index is above the mean value for the sample, a plant is considered to have a high degree of coordination. Respondents reported the nature of material flows among plants in the business unit in Question 3 of the Appendix 2. A plant that has both material flows (to or from other plants in the business unit) and a high degree of coordination is classified as an "integrated plant." We further break down independent plants 
into material flows only (and low managerial coordination), coordination only (and no material flows), and stand-alone (no material flows and low managerial coordination) plants (see Table 3).

Question 1 in Appendix 2 asks about the importance of a variety of determinants of plant location. The determinants of plant location that we consider expand upon similar lists discussed by De Meyer and Vereecke (1994) and Haigh (1990). Respondents were also asked what degree of influence each determinant would have on the decision if it was being made now (Question 2 in Appendix 2). We refer to these two sets of responses as the "Actual Location Decision" or "Then" data, and the "Location Decision Made Now" or "Now" data, respectively.

\section{Factor Analysis of the Location Determinants}

The location determinant variables were first factor analyzed to determine whether it is appropriate to combine some of the determinants within each group. The factors combine determinants that have similar importance to the location decision across all plants as reported by respondents. We did the factor analysis using the principal components method with varimax rotation. The resulting factors were selected on the basis of an eigenvalue greater than 1 or an eigenvalue near 1 and a sharp drop off in the scree plot for the additional factors ( see Table 2).

\section{Hypothesis Development}

\section{Multiple Plant Manufacturing Differences Between Plants}

The manufacturing literature suggests that integrated and independent plants will have different roles and thus different factors are expected to be important to the location decision.

HYPOTHESIS 1a. The determinants of plant location will differ for integrated and independent plants.

TABLE 3

Frequency of Plants by Category

\begin{tabular}{lllllc}
\hline & \multicolumn{4}{c}{ Independent } \\
\cline { 2 - 5 } & $\begin{array}{c}\text { Stand } \\
\text { Alone }\end{array}$ & $\begin{array}{c}\text { Material } \\
\text { Flow Only }\end{array}$ & $\begin{array}{c}\text { Coordination } \\
\text { Only }\end{array}$ & Integrated & All \\
\hline & 24 & 27 & 20 & 35 & 106 \\
A. Domestic & 14.37 & 16.17 & 11.98 & 20.96 & 63.47 \\
\% of total & & & & 31 & 61 \\
Foreign & 7 & 17 & 6 & 18.56 & 36.83 \\
\% of Total & 4.19 & 10.18 & 3.59 & 66 & 167 \\
Total & 31 & 44 & 26 & 39.52 & 100 \\
$\quad$ Column sum as \% of total & 18.56 & 26.35 & 15.57 & 22 & 102 \\
B. United States & 35 & 28 & 17 & 13.17 & 61.08 \\
$\quad \%$ of Total & 20.96 & 16.77 & 10.18 & 4 & 30 \\
Japan & 16 & 8 & 2 & 2.40 & 17.96 \\
$\quad \%$ of Total & 9.58 & 4.79 & 1.20 & 5 & 35 \\
Europe & 15 & 8 & 7 & 2.99 & 20.96 \\
$\quad \%$ of Total & 8.98 & 4.79 & 4.19 & 31 & 167 \\
Column sum & 66 & 44 & 26 & 18.56 & 100 \\
$\quad$ Column sum as \% of total & 39.52 & 26.35 & 15.57 & & \\
\hline
\end{tabular}


Research in international business suggests that location determinants for integrated and independent plants may be moderated by whether it is a foreign or domestic plant.

HYPOTHESIS 1b. The determinants of plant location for integrated and independent plants will differ in foreign locations compared to domestic locations.

\section{International Manufacturing Differences Between Plants}

According to the eclectic theory one of the reasons multinational firms exist is to realize location-specific advantages such as local factor costs which suggests a wide range of location determinants (Dunning 1988, 1993 ).

HYPOTHESIS 2a. The determinants of plant location will differ for foreign and domestic plants.

Location-specific advantages clearly have direct implications for the plant location decision, but the eclectic theory considers that asset ownership advantages may have implications for location choice. Asset ownership advantages include benefits from coordinating assets between plants in different countries (Dunning 1993); however, the relationship between this coordination and the decision to locate a plant in a foreign country has not been explored. The plant location decision is also important for both the flexibility arguments of Kogut $(1985,1989)$ and the international management framework of Prahalad and Doz (1987). However, what is missing in applying these theories to this decision is an explicit consideration of the degree of integration with other plants required by a particular plant and its strategy or mission, rather than the overall degree of integration needed within the multinational business unit. The differences in location determinants for domestic and foreign plants may therefore be moderated by the need for coordination and integration between a plant and other plants in its business unit, the business unit headquarters, or business unit R\&D facilities.

HYPOTHESIS 2b. The determinants of plant location for foreign and domestic plants will differ for integrated plants compared to independent plants.

\section{Expected Relationships in Integrated Versus Independent Plant Location Contrast}

For the integrated versus independent plant location contrast we consider factors within the proximity to network nodes and access to factors of production groups. Key customers can be important sources of learning, and firms with integrated plants can optimize their network to take advantage of this opportunity (Von Hippel 1978). Plant missions within a network can include communicating knowledge gained from key customers to the rest of the network (Ferdows 1989). In this respect, Proximity to Downstream Network Nodes (ProxDown) might be more important for integrated plants because they can specialize in this learning for some of their plants and still transfer this knowledge to other plants. On the other hand, independent plants, that cannot specialize, may define their primary mission as serving a local market or customer. Since these plants are less likely to specialize in other dimensions, as integrated plants can, this determinant might be a more prominent one for independent plants than for integrated plants even though both could conceptually specialize in this way. It is thus an empirical question whether this determinant will favor integrated or independent plants.

Proximity to Upstream Nodes (ProxUp), such as suppliers and other company facilities, is likely to be more important for integrated plants because a plant could specialize its role to learn from suppliers, just as Von Hippel (1978) talked of learning from customers. Integrated plants which engage in coordination among other plants may want to locate near other facilities. Even though independent plants may belong to business units with other facilities, they may not be interested in locating near these facilities since they do no coordination among plants. 
HyPOTHESIS 3. The factor Proximity to Upstream Network Nodes (ProxUp) is a more important location determinant for integrated than for independent plants.

We extend hypothesis 3 to consider differences among types of independent plants. We expect to find that materials flow only plants $(\mathrm{H} 3 . \mathrm{i})$ or coordinated only plants $(\mathrm{H} 3 . \mathrm{ii})$ would be more like integrated plants than stand-alone independent plants. ProxUp should be a more important location determinant for materials flow only plants (H3.i) and for coordinated only plants (H3.ii) than for stand-alone plants.

Where key raw materials or energy are important factors in the cost structure, one expects integrated plants to locate that stage of the production that is raw material intensive in a market with low cost access to raw materials.

HyPOTHESIS 4a. The factor Access to Raw Materials and Energy (RMatEnerg) is a more important location determinant for integrated than for independent plants.

Among independent plants, we again expect RMatEnerg to be least important for standalone independent plants. RMatEnerg should be a more important location determinant for materials flow only plants ( $\mathrm{H} 4 \mathrm{a} . \mathrm{i})$ and for coordinated only plants ( $\mathrm{H} 4 \mathrm{a} . \mathrm{ii})$ than for stand-alone plants.

One would expect a factor measuring Access to Capital and Technology (CapTech) to be most important as a determinant for integrated plant location. Since coordination of firm technology is a central reason for the integrated plants, it is possible that one would locate a pilot or "lookout" plant for access to local technology when using an integrated strategy (Ferdows 1989). Further, to gain access to capital, one might need to locate a plant in a country which might not be justified on other criteria, and the integration with a network would allow this plant to specialize in a capital intensive activity.

HyPOTHESIS 5a. The factor CapTech is a more important location determinant for integrated than for independent plants.

A similar argument would follow for the following factor cost determinants of plant location: Access to Skilled Labor (SkilLab) (H6a) and Access to Low Cost Labor (LCLab) (H7a). Among independent plants, CapTech (H5a), SkilLab (H6a), and LCLab (H7a) should be more important for materials flow only plants (H5a.i) (H6a.i) (H7a.i) and coordinated only plants (H5a.ii) (H6a.ii) (H7a.ii) than for stand-alone plants.

\section{Expected Relationships in Foreign versus Domestic Plant Location Contrast}

We expect only the location determinants involving access to factors of production or national and regional characteristics to be determinants of foreign plant location versus domestic location. Within access to factors of production, we argue that there is greater range of factor cost variation in world markets, and we expect that this will be a primary rationale for the consideration of foreign location relative to domestic location.

RMatEnerg would be more likely to be determinants of foreign plant location than of domestic plant location. If raw materials costs or energy costs are very important to the cost structure, it is likely that companies would pick locations that truly minimize these costs through foreign plant location decisions.

HyPOTHESIS 4b. The factor RMatEnerg is a more important location determinant for foreign than for domestic plants.

Since foreign locations are more likely to have expertise that can only be transferred through access to local engineers, this access to local technology is more likely to be important for foreign than for domestic plant location (Porter 1990, Ch. 5). Also, access to capital could be important because of lower costs of borrowing in some countries than in others. For these reasons we consider CapTech more likely to be a determinant of foreign plant location than of domestic plant location. 
HyPOTHESIS 5b. The factor CapTech is a more important location determinant for foreign than for domestic plants.

Similarly, other access to factors of production determinants would be more likely to be determinants of foreign location than domestic location. These include other factor inputs such as SkilLab (H6b) and LCLab (H7b).

For national or regional characteristics we would expect the differences and opportunities across foreign markets to give firms a chance to pick the characteristics that they seek. Thus these determinants should be more important for the foreign location decision.

Government Policies (GovPol) are important considerations for foreign location decisions. It is well established that government policies such as tariffs and exchange rates can influence foreign direct investment (Caves 1982). Protected markets, tax conditions, regional trade barriers government subsidies, and exchange rate risks can all attract or deter foreign plant locations. Firms can choose locations which best suit their needs in these dimensions, but due to the variety of opportunities across different countries it is more likely that these will be determinants of foreign location decisions. For example, one would expect that the greatest opportunity for transfer pricing and for locating a platform to reduce taxes would occur in foreign locations. In addition, exchange rate risk increases the need to have facilities, and hence costs, located in the markets in which revenues are received (Kogut 1985, 1989). Companies with foreign sales would therefore want to have foreign plants to match these risks. Exchange rate risk should be a location determinant for foreign plants relative to domestic plants if the objective is to avoid risk through direct matching of facilities to markets.

HYPOTHESIS 8. The factor GovPol is a more important location determinant for foreign than for domestic plants.

Societal Characteristics (SocChar) can be influential reasons to locate in a country. Language, culture, and politics or the availability of advanced infrastructure can be necessary conditions for some location decisions. We would expect that these would not be important considerations in domestic location decisions but they might be important determinants when deciding among some foreign locations.

HYPOTHESIS 9. The factor SocChar is a more important location determinant for foreign than for domestic plants.

Similar to the logic for GovPol, for Regulation (Reg) firms should locate their plants to seek out the conditions in which they perform best. Environmental regulations and labor practices and regulation are more likely to be important determinants of foreign plant location.

HyPOTHESIS 10. The factor Reg is a more important location determinant for foreign than for domestic plants.

Indicator variables reflecting whether the business unit headquarters is Japanese- or European-based are also included as explanatory variables. U.S. business unit headquarters are the excluded category and therefore all interpretations are relative to plants with U.S. business unit headquarters.

\section{Model Specification}

The relationship between network strategy and plant location determinants is modeled using a multinomial logit model. The dependent variable represents whether the plant is independent domestic, integrated domestic, independent foreign, or integrated foreign. The explanatory variables are the levels of importance of the location determinant factors to the location decision. The general model takes the following form:

$$
\operatorname{Prob}\left[y_{i}=j\right]=\frac{\exp \left(\hat{\beta} x_{i}\right)}{1+\exp \left(\hat{\beta} x_{i}\right)} \quad \text { for } j=0,1,2,3 \text {, }
$$


where $y_{i}$ is the network strategy for plant $i$, (independent domestic, integrated domestic, independent foreign, and integrated foreign), $x_{i}$ is a vector of importance of factors of location determinants for plant $i$, and $\hat{\beta}$ is a vector of estimated parameters.

\section{Tests of Hypotheses $1 a$ and $2 a$}

Hypotheses $1 \mathrm{a}$ and $2 \mathrm{a}$ examine whether the determinants of plant location differ for foreign and domestic plant location decisions $(\mathrm{Hla})$, and for independent and integrated plants location decisions ( $\mathrm{H} 2 \mathrm{a}$ ). These hypotheses are tested using binomial logit models. The four alternatives in the multinomial model described above are reduced to two. To test $\mathrm{Hla}$, the two alternatives considered are Integrated plants and independent plants with no distinction made between foreign and domestic locations. Similarly, to test H2a, the two alternatives considered are foreign plants and domestic plants with no distinction made between integrated and independent plants. The explanatory variables are the location determinant factors. The logit models were estimated using LIMDEP 6.0 software.

\section{Tests of Hypotheses $1 b$ and $2 b$}

To test Hypotheses $1 \mathrm{~b}$ and $2 \mathrm{~b}$, we examine if adding the foreign/domestic distinction to the existing independent/integrated distinction ( $\mathrm{H} 1 \mathrm{~b}$ ) or adding the independent/integrated distinction to the existing foreign/domestic distinction (H2b) improves the explanatory power of the model. In each case we are essentially comparing a two-alternative model with a four-alternative model.

We developed a method to compare the explanatory power of the four-alternative model with the power of the simpler two-alternative models. These tests are conducted using nested multinomial logit models, but in contrast to the standard nested logit model, the dependent variables rather than the independent variables are nested. Although a log likelihood test is appropriate, because of the type of nesting, the log likelihood statistics of separately estimated two-alternative and four-alternative models cannot be directly compared. Instead, the twoalternative models must be estimated as constrained four-alternative models so that the comparison becomes one between constrained and unconstrained four-alternative models. For example in the test of $\mathrm{H} 1 \mathrm{~b}$, the coefficients for the integrated foreign and integrated domestic alternatives are constrained to be the same and the coefficients for the independent foreign and independent domestic are constrained to be the same. The log likelihood statistic for this constrained model is tested against the log likelihood statistic for the freely estimated fouralternative model. The log likelihood test indicates the significance of the difference in explanatory power of the two models. The test of $\mathrm{H} 2 \mathrm{~b}$ is similar except that the constraints are placed on the integrated foreign and independent foreign coefficients and on the integrated domestic and independent domestic coefficients.

\section{Tests of Hypotheses 3-10}

Hypotheses 3-10 propose specific relationships between individual location determinant factors and the integrated/independent or foreign/domestic plant distinctions. The full four-alternative logit model is used to test these hypotheses. The coefficients on the individual determinants specified in the hypotheses are examined for their significance as discriminators between pairs of alternatives. For example, H3 proposes that ProxUp is a more important location determinant for integrated than for independent plants. If ProxUp is in fact an effective discriminator between integrated and independent plants, the coefficient for that variable in the integrated/independent pair-wise contrast will be significant. The sign on the coefficient indicates which alternative the variable favors: positive coefficients favor either integrated or foreign alternatives.

For the analysis of the three categories of independent plants we used a two-way ANOVA analysis to test for differences in means because we had insufficient cases for some categories to estimate the full logit model. Although ANOVA permits simultaneous multiple contrasts of 
mean responses across categories of plants, it considers only one location determinant factor at a time. In contrast, the logit analysis simultaneously considers all of the location determinant factors and all of the categories of plants. It is the superior approach but demands more degrees of freedom. The ANOVA models were estimated using the Generalized Linear Model procedure in SAS version 6.09. The Generalized Linear Model is necessary when comparing means derived from unbalanced cells (SAS 1990:23).

\section{Empirical Results}

\section{Descriptive Findings}

Rankings of Determinants. One of the most striking features of the descriptive findings (see Part A, Table 4) is that the means for determinants most applicable to Foreign plants, such as regional trade barriers, language/culture/politics, government subsidies, and exchange rate risk, are ranked relatively low as determinants of plant location for all four plant strategies. Only access to advanced infrastructure appears to rank high among this group of variables for all types of plants. For example, exchange rate risk and regional trade barriers are ranked very low. Instead of these factors driving location decisions for foreign plants, they are dominated for these plant strategies by what one might think of as criteria that are considered equally important for domestic plant location, such as proximity to important markets and proximity to key customers. The determinants which reflect access to other network nodes rank uniformly high as plant location determinants.

These findings suggest that plants are not located primarily in multinational plant networks to take advantage of hedging against exchange rate risk or reducing the impact of trade barriers. Instead, it appears that the more important criteria for plant location involve the manufacturing mission or strategy that these plants are chartered to accomplish. This does not mean that exchange rates or other government policies such as tariffs are not associated with direct foreign investment, it only indicates that these determinants are less important than other determinants for the plant location decision.

Since the sample includes plants of different ages and we are relying on retrospective data, we were concerned that there might be differences in rankings of determinants due to age. To investigate this possibility, we divided our sample into "young" plants (less than or equal to 10 years old) and "old" plants (greater than 10 years old) and checked whether there were differences in the rankings of the top five determinants and bottom five determinants between the two subsamples. For independent domestic and independent foreign plants four out of five of the highest and lowest ranking determinants are common to both subsamples. For integrated foreign plants four out of five of the highest ranking determinants and three out of five of the lowest ranking determinants are common to both subsamples. Finally, for integrated domestic, four out of five of the lowest ranking determinants were common to both subsamples, however only two out of five of the highest ranking determinants were shared. Overall, we conclude that there do not seem to be large differences in the rankings of determinants between young and old plants of the same type. However we acknowledge that this similarity in rankings may reflect a "loss of memory"' rather than an actual absence of differences.

Dynamics in Plant Location Rankings. According to a recent conceptual article, new technologies and processes are creating competitive advantage for manufacturing firms that use small flexible plants to add value to customers in terms of delivery, quality, and response time (MacCormack, Newman, and Rosenfeld 1994). This trend is related to manufacturing strategy and therefore there are direct implications for differences between independent and integrated plants. Comparing the "Now" responses with the "Then" responses allows us to investigate this trend.

To avoid exchange rate risk, one must either locate plants in served markets as independent plants or manage the option value of supplying from different locations by man- 
TABLE 4

Means of Location Determinants

\begin{tabular}{|c|c|c|c|c|c|}
\hline \multirow[b]{2}{*}{ Variable Group } & \multirow[b]{2}{*}{ Location Determinant } & \multicolumn{4}{|c|}{$\begin{array}{l}\text { A. Location Determinant Means for Actual } \\
\text { Location Decision }\end{array}$} \\
\hline & & $\begin{array}{l}\text { Integrated } \\
\text { Domestic } \\
(n=35)\end{array}$ & $\begin{array}{c}\text { Independent } \\
\text { Domestic } \\
(n=71)\end{array}$ & $\begin{array}{l}\text { Integrated } \\
\text { Foreign } \\
(n=31)\end{array}$ & $\begin{array}{c}\text { Independent } \\
\text { Foreign } \\
(n=30)\end{array}$ \\
\hline \multirow[t]{4}{*}{$\begin{array}{l}\text { Proximity to } \\
\text { network nodes }\end{array}$} & $\begin{array}{l}\text { Proximity to important } \\
\text { markets }\end{array}$ & $3.00(2)$ & $2.73(3)$ & $3.84(1)$ & $4.13(1)$ \\
\hline & Proximity to key customers & $2.71(7)$ & $2.73(3)$ & $3.45(3)$ & $3.73(2)$ \\
\hline & Proximity to key suppliers & $2.77(4)$ & $2.37(5)$ & $2.52(11)$ & $2.37(6)$ \\
\hline & Proximity to other facilities & $2.74(5)$ & $2.35(7)$ & $2.00(16)$ & $2.07(10)$ \\
\hline \multirow[t]{6}{*}{ Factor costs } & Access to raw materials & $2.71(7)$ & $1.79(10)$ & $2.48(12)$ & $2.13(9)$ \\
\hline & Access to low cost labor & $2.66(9)$ & $2.15(8)$ & $2.87(7)$ & $2.53(5)$ \\
\hline & Access to skilled labor & $3.34(1)$ & $3.07(1)$ & $3.35(4)$ & $2.77(4)$ \\
\hline & Access to energy & $2.94(3)$ & $2.25(6)$ & $2.84(8)$ & $2.30(7)$ \\
\hline & Access to capital & $1.57(14)$ & $1.17(14)$ & $2.19(13)$ & $0.90(19)$ \\
\hline & Access to local technology & $1.60(13)$ & $1.65(11)$ & $1.90(17)$ & $1.10(18)$ \\
\hline \multirow{9}{*}{$\begin{array}{l}\text { National or regional } \\
\text { characteristics }\end{array}$} & Access to protected markets & $1.17(16)$ & $0.68(17)$ & $1.48(18)$ & $1.53(13)$ \\
\hline & Tax conditions & $2.11(11)$ & $1.55(12)$ & $2.61(9)$ & $1.73(12)$ \\
\hline & Regional trade barriers & $0.63(18)$ & $0.65(18)$ & $1.42(19)$ & $1.30(15)$ \\
\hline & Government subsidies & $1.00(17)$ & $1.01(16)$ & $2.61(9)$ & $1.20(16)$ \\
\hline & Language, culture, politics & $1.46(15)$ & $1.08(15)$ & $3.06(5)$ & $2.20(8)$ \\
\hline & Advanced infrastructure & $2.74(5)$ & $2.83(2)$ & $3.55(2)$ & $2.93(3)$ \\
\hline & Labor practices and regulation & $2.31(10)$ & $2.15(8)$ & $2.97(6)$ & $2.00(11)$ \\
\hline & Environmental regulation & $1.86(12)$ & $1.52(13)$ & $2.06(15)$ & $1.40(14)$ \\
\hline & Exchange rate risk & $0.63(18)$ & $0.46(19)$ & $2.10(14)$ & $1.17(17)$ \\
\hline & & \multicolumn{4}{|c|}{$\begin{array}{l}\text { B. Location Determinant Means if Location Decision } \\
\text { Was Made Now }\end{array}$} \\
\hline Variable Group & Location Determinant & $\begin{array}{l}\text { Integrated } \\
\text { Domestic } \\
(n=37)\end{array}$ & $\begin{array}{c}\text { Independent } \\
\text { Domestic } \\
(n=62)\end{array}$ & $\begin{array}{l}\text { Integrated } \\
\text { Foreign } \\
(n=31)\end{array}$ & $\begin{array}{c}\text { Independent } \\
\text { Foreign } \\
(n=32)\end{array}$ \\
\hline \multirow[t]{4}{*}{$\begin{array}{l}\text { Proximity to } \\
\text { network nodes }\end{array}$} & $\begin{array}{l}\text { Proximity to important } \\
\text { markets }\end{array}$ & $3.22(5)$ & $3.15(3)$ & $3.54(2)$ & $3.94(1)$ \\
\hline & Proximity to key customers & $3.08(8)$ & $3.05(5)$ & $3.22(7)$ & $3.81(2)$ \\
\hline & Proximity to key suppliers & $3.11(7)$ & $2.87(8)$ & $2.64(12)$ & $2.69(7)$ \\
\hline & Proximity to other facilities & $2.92(10)$ & $2.48(12)$ & $2.32(16)$ & $2.34(10)$ \\
\hline \multirow[t]{6}{*}{ Factor costs } & Access to raw materials & $2.78(12)$ & $2.60(11)$ & $2.61(13)$ & $2.56(9)$ \\
\hline & Access to low cost labor & $2.97(9)$ & $2.73(10)$ & $3.19(8)$ & $2.78(6)$ \\
\hline & Access to skitled labor & $3.73(1)$ & $3.40(2)$ & $3.48(3)$ & $3.25(3)$ \\
\hline & Access to energy & $3.41(3)$ & $2.77(9)$ & $2.97(10)$ & $2.34(10)$ \\
\hline & Access to capital & $1.78(16)$ & $1.60(17)$ & $2.29(17)$ & $1.59(18)$ \\
\hline & Access to local technology & $2.35(13)$ & $2.37(13)$ & $2.48(15)$ & $1.97(15)$ \\
\hline \multirow{9}{*}{$\begin{array}{l}\text { National or regional } \\
\text { characteristics }\end{array}$} & Access to protected markets & $1.65(17)$ & $1.35(19)$ & $1.90(19)$ & $1.40(19)$ \\
\hline & Tax conditions & $2.86(11)$ & $3.02(7)$ & $3.25(6)$ & $2.06(14)$ \\
\hline & Regional trade barriers & $1.57(18)$ & $1.39(18)$ & $2.03(18)$ & $1.88(16)$ \\
\hline & Government subsidies & $2.00(15)$ & $2.10(15)$ & $2.97(10)$ & $1.84(17)$ \\
\hline & Language, culture, politics & $2.32(14)$ & $2.11(14)$ & $3.45(4)$ & $2.25(12)$ \\
\hline & Advanced infrastructure & $3.46(2)$ & $3.50(1)$ & $3.83(1)$ & $3.25(3)$ \\
\hline & Labor practices and regulation & $3.16(6)$ & $3.08(4)$ & $3.45(4)$ & $2.66(8)$ \\
\hline & Environmental regulation & $3.27(4)$ & $3.05(5)$ & $3.12(9)$ & $2.81(5)$ \\
\hline & Exchange rate risk & $1.38(19)$ & $1.65(16)$ & $2.51(14)$ & $2.13(13)$ \\
\hline
\end{tabular}


aging plants as a network to achieve flexibility. Independent plants would be hedged for fluctuations in their market alone. To add flexibility to a network of plants would require the use of integrated foreign plants (Kogut 1985, 1989). MacCormack, Newman, and Rosenfeld (1994) suggest that there is a trend toward the growth of trade and the easing of government restrictions on trade. One might infer then that avoiding exchange rate risks would become more important over time for integrated foreign plants. In other words, exchange rate risk should be increasing in importance for the foreign integrated plants relative to foreign independent plants. Instead, it appears that firms are increasingly locating independent plants in foreign locations to reduce exposure to exchange rate risk. The relative rank of means has stayed the same at 14th for exchange rate risk for the integrated foreign location choice, but has risen considerably for the Independent foreign location choice (17th to 13 th $)$ (Table 4).

\section{Estimation Results}

INTEGRATED VERSUS INDEPENDENT PLANTS. The significant chi-square statistic (24.37, d.f. $=11$ ) for the two-alternative integrated versus independent logit model (Table 5 , column 1 ) indicates that the location determinants do discriminate between the integrated and independent plants, consistent with $\mathrm{H} 1 \mathrm{a}$. So, the distinction between integrated and independent plants with respect to location decisions is an important one to make.

TABLE 5

Logit Model Of Plant Location

\begin{tabular}{|c|c|c|}
\hline & Integrated vs. Independent & Foreign vs. Domestic \\
\hline Constant & $\begin{array}{l}-0.070 * * * \\
(-3.06)\end{array}$ & $\begin{array}{l}-1.66^{* * *} \\
(-5.28)\end{array}$ \\
\hline \multicolumn{3}{|l|}{ Proximity to network nodes } \\
\hline $\begin{array}{l}\text { Proximity to downstream nodes } \\
\text { (ProxDown) }\end{array}$ & $\begin{array}{c}-0.09 \\
(-0.46)\end{array}$ & $\begin{array}{l}1.05 * * * \\
(3.73)\end{array}$ \\
\hline Proximity to upstream nodes (ProxUp) & $\begin{array}{c}-0.06 \\
(-0.33)\end{array}$ & $\begin{array}{r}-0.41^{\dagger} \\
(-1.59)\end{array}$ \\
\hline \multicolumn{3}{|l|}{ Access to factors of production } \\
\hline Raw materials and energy (RMatEnerg) & $\begin{array}{l}+0.50^{* *} \\
(+2.50)\end{array}$ & $\begin{array}{l}-0.11 \\
(-0.46)\end{array}$ \\
\hline Capital and local technology (CapTech) & $\begin{array}{c}+0.32^{*} \\
(+1.65)\end{array}$ & $\begin{array}{l}-0.25 \\
(-1.02)\end{array}$ \\
\hline Skilled labor (SkilLab) & $\begin{array}{c}+0.08 \\
(+0.41)\end{array}$ & $\begin{array}{l}-0.04 \\
(-0.19)\end{array}$ \\
\hline Low cost labor (LCLab) & $\begin{array}{c}+0.31^{\dagger} \\
(+1.54)\end{array}$ & $\begin{array}{c}-0.11 \\
(-0.43)\end{array}$ \\
\hline \multicolumn{3}{|l|}{ National or regional characteristics } \\
\hline Government policies (GovPol) & $\begin{array}{c}+0.14 \\
(+0.71)\end{array}$ & $\begin{array}{l}0.80^{* * * *} \\
(3.21)\end{array}$ \\
\hline Societal characteristics (SocChar) & $\begin{array}{r}+0.31^{*} \\
(+1.70)\end{array}$ & $\begin{array}{l}0.095^{* * * *} \\
(3.86)\end{array}$ \\
\hline Regulations (Reg) & $\begin{array}{c}+0.05 \\
(+0.25)\end{array}$ & $\begin{array}{c}-0.27 \\
(-1.15)\end{array}$ \\
\hline Japanese parent (Japan) & $\begin{array}{c}+0.036 \\
(+0.76)\end{array}$ & $\begin{array}{l}2.34^{* * * *} \\
(3.66)\end{array}$ \\
\hline European parent (Europe) & $\begin{array}{c}+0.63^{\dagger} \\
(+1.42) \\
\text { Log likelihood }(\hat{\beta})=-99.88 \\
\text { Log likelihood }(0)=-112.06 \\
\chi^{2}(11)=24.37 ; p<0.011\end{array}$ & $\begin{array}{c}1.63 * * * \\
(2.99) \\
\text { Log likelihood }(\hat{\beta})=-69.64 \\
\text { Log likelihood }(0)=-109.62 \\
\chi^{2}(11)=79.95 ; p<0.006\end{array}$ \\
\hline
\end{tabular}

$* * *|p|<0.01 ; * *<0.05 ; *<0.10 ;^{\dagger}<0.20$. 
TABLE 6

Logit Model of Plant Location Decision

\begin{tabular}{|c|c|c|c|c|}
\hline & \multicolumn{4}{|c|}{ Actual Location Decision } \\
\hline & $\begin{array}{c}(1) \\
\text { Integ. Domestic. } \\
\text { vs. Indep. Domestic }\end{array}$ & $\begin{array}{l}(2) \\
\text { Integ. Foreign vs. } \\
\text { Indep. Foreign }\end{array}$ & $\begin{array}{l}\text { (3) } \\
\text { Indep. Foreign vs. } \\
\text { Indep. Domestic }\end{array}$ & $\begin{array}{c}\text { (4) } \\
\text { Integ. Foreign vs. } \\
\text { Integ. Domestic }\end{array}$ \\
\hline Constant & $\begin{array}{l}-0.93 * * * \\
(-3.25)\end{array}$ & $\begin{array}{l}0.53 \\
(-0.89)\end{array}$ & $\begin{array}{l}-1.92^{* * *} \\
(-4.69)\end{array}$ & $\begin{array}{l}-1.52 * * * \\
(-2.81)\end{array}$ \\
\hline \multicolumn{5}{|l|}{ Network nodes } \\
\hline $\begin{array}{l}\text { Proximity to } \\
\text { downstream } \\
\text { nodes } \\
\text { (ProxDown) }\end{array}$ & $\begin{array}{l}-0.14 \\
(-0.59)\end{array}$ & $\begin{array}{l}-0.41 \\
(-1.04)\end{array}$ & $\begin{array}{l}1.18 * * * \\
(3.27)\end{array}$ & $\begin{array}{l}0.90 * * \\
(2.37)\end{array}$ \\
\hline $\begin{array}{l}\text { Proximity to } \\
\text { upstream nodes } \\
\text { (ProxUp) }\end{array}$ & $\begin{array}{l}0.31 \\
(1.19)\end{array}$ & $\begin{array}{l}-0.58^{\dagger} \\
(-1.59)\end{array}$ & $\begin{array}{l}-0.05 \\
(0.17)\end{array}$ & $\begin{array}{l}-0.95^{* *} \\
(-2.41)\end{array}$ \\
\hline \multicolumn{5}{|l|}{$\begin{array}{c}\text { Access to factors of } \\
\text { production }\end{array}$} \\
\hline $\begin{array}{l}\text { Raw materials and } \\
\text { energy } \\
\text { (RMatEnerg) }\end{array}$ & $\begin{array}{l}0.87 \\
(3.10)^{* * *}\end{array}$ & $\begin{array}{l}-0.55^{\dagger} \\
(1.52)\end{array}$ & $\begin{array}{l}-0.01 \\
(-0.03)\end{array}$ & $\begin{array}{l}-0.32 \\
(-0.83)\end{array}$ \\
\hline $\begin{array}{l}\text { Capital and local } \\
\text { technology } \\
\text { (CapTech) }\end{array}$ & $\begin{array}{l}-0.01 \\
(-0.05)\end{array}$ & $\begin{array}{l}0.96 * * * \\
(2.63)\end{array}$ & $\begin{array}{l}-0.73 * * \\
(-2.21)\end{array}$ & $\begin{array}{l}0.24 \\
(0.67)\end{array}$ \\
\hline $\begin{array}{l}\text { Skilled labor } \\
\text { (SkilLab) }\end{array}$ & $\begin{array}{l}-0.02 \\
(-0.06)\end{array}$ & $\begin{array}{l}0.17 \\
(0.53)\end{array}$ & $\begin{array}{l}-0.14 \\
(-0.51)\end{array}$ & $\begin{array}{l}0.04 \\
(0.12)\end{array}$ \\
\hline $\begin{array}{l}\text { Low cost labor } \\
\quad(\text { LCLab) }\end{array}$ & $\begin{array}{l}0.58^{* *} \\
(2.10)\end{array}$ & $\begin{array}{l}0.12 \\
(0.36)\end{array}$ & $\begin{array}{l}0.10 \\
(0.32)\end{array}$ & $\begin{array}{l}-0.36 \\
(-0.94)\end{array}$ \\
\hline \multicolumn{5}{|l|}{$\begin{array}{l}\text { National } \\
\text { characteristics }\end{array}$} \\
\hline $\begin{array}{l}\text { Government } \\
\text { policies (GovPol) }\end{array}$ & $\begin{array}{l}0.10 \\
(0.32)\end{array}$ & $\begin{array}{l}0.03 \\
(0.10)\end{array}$ & $\begin{array}{l}0.87^{* * *} \\
(2.87)\end{array}$ & $\begin{array}{l}0.79 * * \\
(2.10)\end{array}$ \\
\hline $\begin{array}{l}\text { Societal } \\
\text { characteristics } \\
\text { (SocChar) }\end{array}$ & $\begin{array}{l}-0.21 \\
(-0.76)\end{array}$ & $\begin{array}{l}0.63^{*} \\
(1.93)\end{array}$ & $\begin{array}{l}0.58 * * \\
(1.98)\end{array}$ & $\begin{array}{l}1.42^{* * *} \\
(3.83)\end{array}$ \\
\hline Regulations (Reg) & $\begin{array}{l}-0.06 \\
(-0.23)\end{array}$ & $\begin{array}{l}0.12 \\
(0.34)\end{array}$ & $\begin{array}{l}-0.38^{\dagger} \\
(-1.28)\end{array}$ & $\begin{array}{l}-0.20 \\
-0.59\end{array}$ \\
\hline $\begin{array}{l}\text { Japanese parent } \\
\text { (Japan) }\end{array}$ & $\begin{array}{l}-1.10^{\dagger} \\
(-1.30)\end{array}$ & $\begin{array}{l}0.91 \\
(1.17)\end{array}$ & $\begin{array}{l}1.48^{*} \\
(1.90)\end{array}$ & $\begin{array}{l}3.49 * * * \\
(3.52)\end{array}$ \\
\hline $\begin{array}{l}\text { European parent } \\
\text { (Europe) }\end{array}$ & $\begin{array}{l}1.20^{*} \\
(1.83)\end{array}$ & $\begin{array}{l}0.07 \\
(0.09)\end{array}$ & $\begin{array}{l}2.19 * * \\
(3.18)\end{array}$ & $\begin{array}{l}1.06^{\dagger} \\
1.32\end{array}$ \\
\hline
\end{tabular}

Four choice unconstrained model: independent domestic, integrated domestic, independent foreign, integrated foreign. $\log$ likelihood $(\hat{\beta})=-157.53 ; \log$ likelihood $(0)=-219.13 ; \chi^{2}$ (d.f. $\left.=36-3=33\right)=123.20(p<0.000)$.

$* * *|p|<0.01 ; * *<0.05 ; *<0.10{ }^{\dagger}<0.20$.

Hypotheses $\mathrm{H} 3, \mathrm{H} 4 \mathrm{a}, \mathrm{H} 5 \mathrm{a}, \mathrm{H} 6 \mathrm{a}$, and $\mathrm{H7}$ a specify particular location determinants in the proximity to network nodes and access to factors of production groups that were expected to discriminate between integrated and independent plants. Surprisingly, we find no significant differences in terms of the need to locate for ProxUp such as key suppliers and other company facilities; there is no support for our Hypothesis 3. Within access to factors of production, we find that RMatEnerg and CapTech have the expected positive and significant coefficient which supports our Hypothesis $4 a$ and 5a (Table 5, column 1). Access to these important factors of production differentiates the location choices for integrated plants compared to independent plants because integrated plants can specialize for access to these inputs and serve the rest of the network with advantages derived from this specialization. For example, integrated plants may specialize in capital intensive or 
technically sophisticated processes that benefit from being located in countries with these endowments. Hypotheses $6 a$ and 7 a concerning SkilLab and LCLab are not supported.

Does the distinction between foreign and domestic contexts moderate the location determinants for the integrated versus independent plant distinction as proposed by $\mathrm{H} 1 \mathrm{~b}$ ? The log likelihood test of the nested logit models indicates that it does. A significant chisquare statistic $(116.21$, d.f. $=24)$ indicates that adding the distinction between foreign and domestic contexts adds to the explanatory power of the model consistent with $\mathrm{H} 1 \mathrm{~b}$. The simpler two-alternative model without the foreign/domestic distinction is rejected.

Adding the foreign/domestic distinction also provides further insights into the relationships hypothesized in $\mathrm{H} 3, \mathrm{H} 4 \mathrm{a}, \mathrm{H} 5 \mathrm{a}, \mathrm{H6a}$, and $\mathrm{H} 7 \mathrm{a}$.

Integrated Versus Independent Choices-Domestic. Within domestic plants the findings (Table 6, column 1) are very similar to the results for all plants (Table 5, column 1) except CapTech is no longer significant and LCLab moves from marginally significant to significant. As before, RMatEnerg is significant in the domestic context. An explanation might be that integrated domestic plants may have developed as parts of firms pursuing local advantages in things like raw materials, energy, and low cost labor.

Integrated Versus Independent Choices-Foreign. RMatEnerg is no longer significant in the foreign context and CapTech remains significant (Table 6, column 2). The differences between the variables that are significant in the foreign and domestic contexts may be because advantages based on raw materials, energy, and low cost labor require integration of material flows that are linked to facilities predominantly in the home country, while advantages based on capital and local technology requires integration of knowledge deriving from local technology in many settings. Integration of knowledge and technical expertise in the foreign context may be less difficult and hence more important reasons for integration than material flows.

Further Investigation of the Integrated Versus Independent Choices. We investigate $\mathrm{H3}, \mathrm{H} 4 \mathrm{a}, \mathrm{H} 5 \mathrm{a}, \mathrm{H6a}$, and $\mathrm{H} 7 \mathrm{a}$ for the case in which independent plants are divided into stand-alone, materials only, and coordination only plants. When we replace independent plants with the more narrowly defined stand-alone plants, we find some significant differences that we did not find when integrated plants were compared to the broader definition of independent plants. For example, there is a significant positive difference in ProxUp for integrated domestic versus stand-alone domestic plants ( $\mathrm{H} 3$, Table 7). The result in H3 is consistent with what Schmenner, Huber, and Cook (1987) find in the domestic context: that manufacturing decisions influence location decisions which might ordinarily be made on geographic factors. LCLab and Reg also discriminate between integrated foreign and stand-alone foreign (Table 7) but did not discriminate between integrated foreign and independent foreign (Table 6).

We also test extensions of the above hypotheses to determine whether there are important distinctions among stand-alone, materials flow only, and coordination only plants which we had previously pooled together as independent plants. There is support for $\mathrm{H} 7 \mathrm{a} . \mathrm{i}$ : the mean of the LCLab is significantly higher in materials flow only plants than for standalone plants in the foreign context (Table 8). The RMatEnerg factor has a significantly higher mean for coordinated only plants than for stand-alone plants in both the domestic and foreign context (H4a.ii, Table 9). There is also support for H5a.ii: the mean of CapTech is higher for coordination only plants in the domestic context. Coordination only plants seem to be more similar to integrated plants than to stand-alone plants in the importance of these access to factors of production. There is a significant positive difference in ProxUp for coordination only versus stand-alone foreign plants as well (H3.ii, Table 9). Coordination only plants emphasize ProxUp in location decisions. The result in H3.ii confirms the need to extend the Schmenner, Huber, and Cook (1987) finding to the foreign context; geographic factors moderate manufacturing determinants. Since coordination does not involve materials flows within the company, it raises the question of whether 
TABLE 7

Differences in Factor Means for Integrated Plants vs. Stand Alone Plants in Both Foreign and Domestic Contexts

\begin{tabular}{|c|c|c|c|c|}
\hline & \multicolumn{4}{|c|}{ Actual Location Decision } \\
\hline & $\begin{array}{l}\text { (1) } \\
\text { Integrated } \\
\text { Domestic vs. } \\
\text { Stand Alone } \\
\text { Domestic }\end{array}$ & $\begin{array}{c}(2) \\
\text { Integrated } \\
\text { Foreign vs. } \\
\text { Stand Alone } \\
\text { Foreign }\end{array}$ & $\begin{array}{l}\text { (3) } \\
\text { Stand Alone } \\
\text { Foreign vs. } \\
\text { Stand Alone } \\
\text { Domestic }\end{array}$ & $\begin{array}{l}(4) \\
\text { Integrated Foreign } \\
\text { vs. Integrated } \\
\text { Domestic }\end{array}$ \\
\hline \multicolumn{5}{|l|}{ Network nodes } \\
\hline Proximity to downstream & 0.19 & 0.00 & 0.71 & $0.52 * *$ \\
\hline nodes (ProxDown) & $(0.47)$ & $(1.00)$ & $(0.91)$ & $(0.03)$ \\
\hline Proximity to upstream & $0.46 *$ & 0.30 & -0.36 & $-0.52 * *$ \\
\hline nodes (ProxUp) & $(0.08)$ & $(0.46)$ & $(0.39)$ & $(0.04)$ \\
\hline \multicolumn{5}{|l|}{$\begin{array}{l}\text { Access to factors of } \\
\text { production }\end{array}$} \\
\hline Raw materials and energy & $0.37^{\dagger}$ & 0.05 & 0.10 & -0.22 \\
\hline (RMatEnerg) & $(0.14)$ & $(0.91)$ & $(0.80)$ & $(0.34)$ \\
\hline Capital and local technology & -0.01 & $0.96 * *$ & -0.52 & $0.43 *$ \\
\hline (CapTech) & $(0.98)$ & $(0.02)$ & $(0.21)$ & $(0.06)$ \\
\hline \multirow[t]{2}{*}{ Skilled labor (SkilLab) } & 0.12 & 0.38 & -0.31 & -0.05 \\
\hline & $(0.65)$ & $(0.36)$ & $(0.48)$ & $(0.85)$ \\
\hline \multirow[t]{2}{*}{ Low cost labor (LCLab) } & 0.28 & $0.70^{*}$ & -0.20 & 0.22 \\
\hline & $(0.27)$ & $(0.09)$ & $(0.65)$ & $(0.37)$ \\
\hline \multicolumn{5}{|l|}{ National characteristics } \\
\hline Government policies & 0.06 & 0.45 & 0.19 & $0.58^{* *}$ \\
\hline (GovPol) & $(0.80)$ & $(0.26)$ & $(0.65)$ & $(0.02)$ \\
\hline Societal characteristics & 0.18 & $1.34 * * *$ & -0.17 & $0.99 * * *$ \\
\hline (SocChar) & $(0.46)$ & $(0.00)$ & $(0.66)$ & $(0.00)$ \\
\hline \multirow{2}{*}{ Regulations (Reg) } & 0.35 & $0.79 *$ & -0.57 & -0.13 \\
\hline & $(0.20)$ & $(0.06)$ & $(0.18)$ & $(0.61)$ \\
\hline
\end{tabular}

Two-way ANOVA using general linear model procedure.

*** $|p|<0.01 ; * *<0.05 ;^{*}<0.10 ;^{\dagger}<0.20$. $P$ values required for significance in one-tailed tests.

there are differences within coordination only firms in terms of those that coordinate with headquarters over sourcing and R\&D versus those that coordinate with other plants.

Accordingly, we check whether there would be differences in the location determinants depending on the form of the coordination. We find that there is very little significant difference between plant location determinants for plants that are coordinated with headquarters versus those that are coordinated with other plants.

FOREIGN VERSUS DOMESTIC PLANTS. The significant chi-square statistic (79.95, d.f. $=11$ ) for the two-alternative foreign versus domestic logit model (Table 5, column 2) indicates that the location determinants discriminate between foreign and domestic plants, consistent with $\mathrm{H} 2 \mathrm{a}$.

We expected differences in the importance of access to factors of production and national or regional characteristics between foreign and domestic plants. Contrary to $\mathrm{H} 4 \mathrm{~b}$, $\mathrm{H} 5 \mathrm{~b}, \mathrm{H} 6 \mathrm{~b}$, and $\mathrm{H} 7 \mathrm{~b}$, the coefficients of the factors of production determinants are not significant (Table 5, column 2). From the national or regional characteristic group, GovPol and SocChar are significant discriminators of foreign and domestic plants; they are more important determinants for locating foreign plants as expected in $\mathrm{H} 8$ and $\mathrm{H} 9$. The Japanese Parent dummy variable as well as the European Parent dummy variable are significant in the foreign versus domestic contrast. In other words, plants with Japanese parents and European parents are more likely than plants with U.S. parents to be located outside of the home country. 
TABLE 8

Differences in Factor Means for Materials Flow Only Plants vs. Stand Alone Plants in Both Foreign and Domestic Contexts

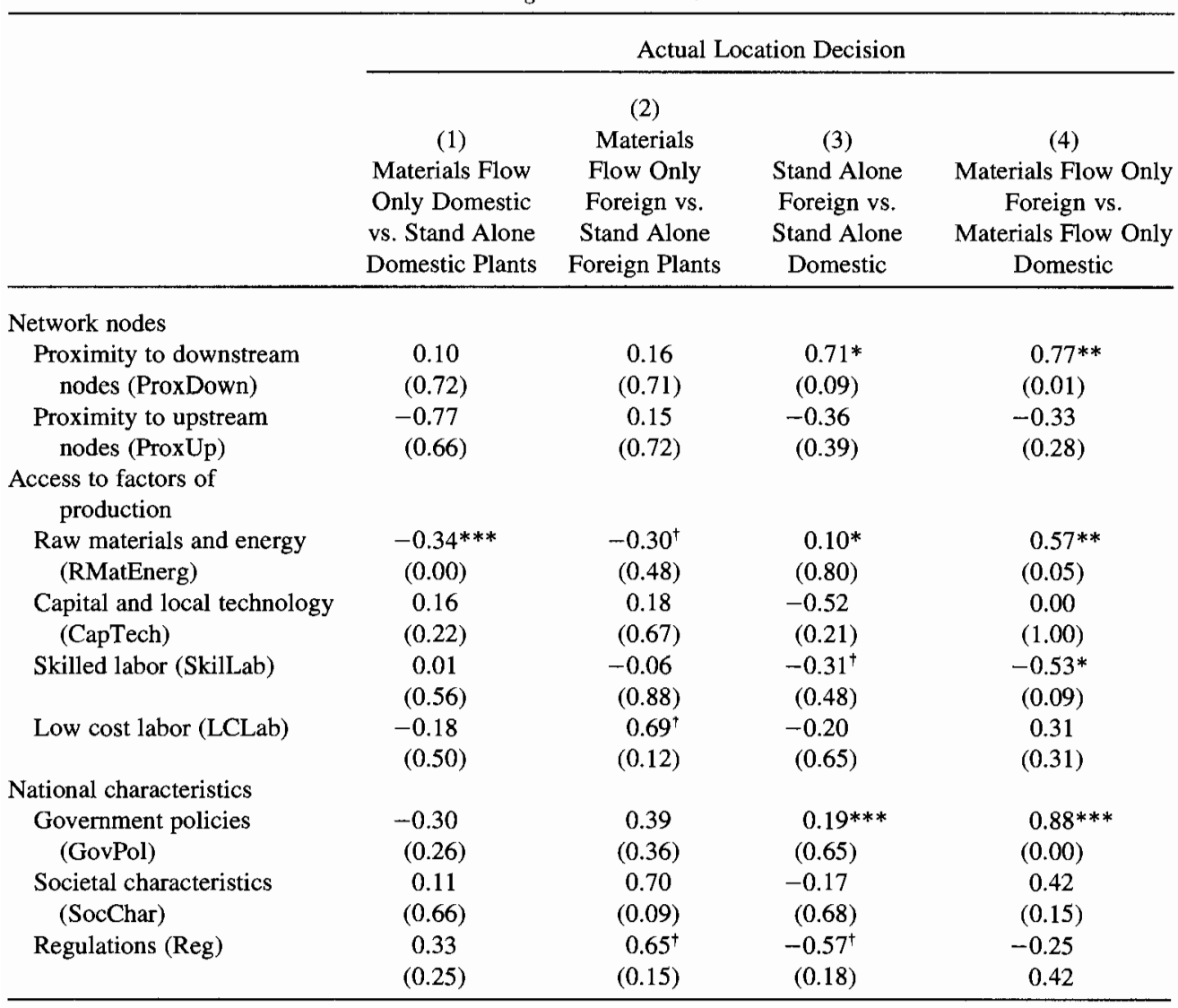

Two-way ANOVA using general linear model procedure.

${ }^{* * *}|p|<0.01 ; * *<0.05 ;^{*}<0.10 ;^{\dagger}<0.20$. $P$ values required for significance in one-tailed tests.

Does the distinction between independent and integrated contexts moderate the location determinants for the foreign versus domestic plant distinction as proposed by $\mathrm{H} 2 \mathrm{~b}$ ? A significant chi-square statistic $(55.74$, d.f. $=24)$ from the log likelihood test of the nested logit models supports the hypothesized moderated relationship. Adding the distinction between independent and integrated plants increases the explanatory power of the model. This is support for the international management literature which incorporates the contingencies of plant coordination and country differences (Prahalad and Doz 1987). The simpler two-alternative model without the independent/integrated distinction is rejected. Adding the independent/integrated distinction also provides further insights into the relationships hypothesized in $\mathrm{H} 4 \mathrm{~b}, \mathrm{H} 5 \mathrm{~b}, \mathrm{H} 6 \mathrm{~b}, \mathrm{H} 7 \mathrm{~b}, \mathrm{H} 8$, and $\mathrm{H} 9$.

Foreign Versus Domestic Choices-Independent. These results continue to hold in the independent plant context with the exception that CapTech is a negative and significant discriminant, and is therefore a more important discriminant for the domestic plants (Table 6 , column 3). Some of these plants must be domestic champions and get subsidies for capital or the technology they need is well developed in the domestic context, which may be partly related to their existence in a particular country in the first place.

Foreign Versus Domestic Choices - Integrated. This contrast for integrated plants (Table 6 , column 4) is also very similar to the foreign versus domestic contrast for all plants except for the significant negative coefficient on ProxUp. It is more important for integrated domestic 
TABLE 9

Differences in Factor Means for Coordinated Only Plants vs. Stand Alone Plants in Both Foreign and Domestic Contexts

\begin{tabular}{|c|c|c|c|c|}
\hline & \multicolumn{4}{|c|}{ Actual Location Decision } \\
\hline & $\begin{array}{c}(1) \\
\text { Coordinated } \\
\text { Domestic vs. } \\
\text { Stand Alone } \\
\text { Domestic Plants }\end{array}$ & $\begin{array}{l}\text { (2) } \\
\text { Coordinated } \\
\text { Foreign vs. } \\
\text { Stand Alone } \\
\text { Foreign Plants }\end{array}$ & $\begin{array}{l}(3) \\
\text { Stand Alone } \\
\text { Foreign vs. } \\
\text { Stand Alone } \\
\text { Domestic }\end{array}$ & $\begin{array}{l}(4) \\
\text { Coordinated } \\
\text { Foreign vs. } \\
\text { Coordinated } \\
\text { Domestic }\end{array}$ \\
\hline \multicolumn{5}{|l|}{ Nètwork nodes } \\
\hline $\begin{array}{l}\text { Proximity to downstream } \\
\text { nodes (ProxDown) }\end{array}$ & $\begin{array}{c}0.16 \\
(0.59)\end{array}$ & $\begin{array}{c}0.31 \\
(0.56)\end{array}$ & $\begin{array}{l}0.71 * \\
(0.09)\end{array}$ & $\begin{array}{l}0.86^{*} \\
(0.06)\end{array}$ \\
\hline $\begin{array}{l}\text { Proximity to upstream } \\
\text { nodes (ProxUp) }\end{array}$ & $\begin{array}{c}0.35 \\
(0.25)\end{array}$ & $\begin{array}{l}0.91^{*} \\
(0.10)\end{array}$ & $\begin{array}{c}-0.36 \\
(0.39)\end{array}$ & $\begin{array}{c}0.20 \\
(0.66)\end{array}$ \\
\hline \multicolumn{5}{|l|}{$\begin{array}{l}\text { Access to factors of } \\
\text { production }\end{array}$} \\
\hline $\begin{array}{l}\text { Raw materials and energy } \\
\text { (RMatEnerg) }\end{array}$ & $\begin{array}{l}0.14^{* * *} \\
(0.61)\end{array}$ & $\begin{array}{r}0.44^{+} \\
(0.40)\end{array}$ & $\begin{array}{l}0.10^{*} \\
(0.80)\end{array}$ & $\begin{array}{c}0.40 \\
(0.37)\end{array}$ \\
\hline $\begin{array}{l}\text { Capital and local technology } \\
\text { (CapTech) }\end{array}$ & $\begin{array}{r}0.40^{\dagger} \\
(0.18)\end{array}$ & $\begin{array}{c}0.09 \\
(0.86)\end{array}$ & $\begin{array}{l}-0.52 \\
(0.21)\end{array}$ & $\begin{array}{c}-0.83^{*} \\
(0.07)\end{array}$ \\
\hline Skilled labor (SkilLab) & $\begin{array}{c}0.19 \\
(0.52)\end{array}$ & $\begin{array}{c}0.69 \\
(0.22)\end{array}$ & $\begin{array}{r}-0.31^{f} \\
(0.48)\end{array}$ & $\begin{array}{c}0.19 \\
(0.69)\end{array}$ \\
\hline Low cost labor (LCLab) & $\begin{array}{r}-0.34^{\dagger} \\
(0.26)\end{array}$ & $\begin{array}{c}0.15 \\
(0.79)\end{array}$ & $\begin{array}{c}-0.20 \\
(0.65)\end{array}$ & $\begin{array}{c}0.29 \\
(0.52)\end{array}$ \\
\hline \multicolumn{5}{|l|}{ National characteristics } \\
\hline Government policies & $\begin{array}{c}-0.09 \\
(0.75)\end{array}$ & $\begin{array}{c}0.09 \\
(0.87)\end{array}$ & $\begin{array}{l}0.19^{* * *} \\
(0.65)\end{array}$ & $\begin{array}{c}0.37 \\
(0.41)\end{array}$ \\
\hline $\begin{array}{l}\text { Societal characteristics } \\
\text { (SocChar) }\end{array}$ & $\begin{array}{r}0.40^{\dagger} \\
(0.16)\end{array}$ & $\begin{array}{r}0.84^{\dagger} \\
(0.11)\end{array}$ & $\begin{array}{c}-0.17 \\
(0.68)\end{array}$ & $\begin{array}{c}0.27 \\
(0.53)\end{array}$ \\
\hline Regulations (Reg) & $\begin{array}{c}0.16 \\
(0.61)\end{array}$ & $\begin{array}{c}0.57 \\
(0.30)\end{array}$ & $\begin{array}{r}-0.57^{\dagger} \\
(0.18)\end{array}$ & $\begin{array}{l}-0.16 \\
(0.74)\end{array}$ \\
\hline
\end{tabular}

Two-way ANOVA using general linear model procedure.

${ }^{* * *}|p|<0.01 ; * *<0.05 ; *<0.10 ;^{\dagger}<0.20 . P$ values required for significance in one-tailed tests.

plants to be close to key suppliers and other facilities of the company than it is for integrated foreign plants. Some integrated plants need to be in close proximity to important resources and activities in the firm such as corporate R\&D, and this may lead them to choose domestic location where key firm activities reside (Bartmess and Cerny 1993).

\section{Discussion and Conclusions}

This study develops a framework and empirically investigates the combined importance of international business and manufacturing strategy literature for the plant location choice in multinational firms. In our framework, the essential choice that is related to manufacturing strategy is the choice between locating an independent versus an integrated plant. The respective choice for international business involves one between a domestic versus a foreign plant. We first consider the determinants of each choice and then consider whether the context of the choice matters. In other words, does the international context matter for the manufacturing strategy choice? Second, does the manufacturing context matter for the international business choice? The results confirm the simple typology we needed to contrast the relative importance and significance of manufacturing strategy with international business determinants. Each perspective benefits from consideration of issues that are a primary focus of the other, and we conclude that a combined perspective provides a better understanding of the plant location decision than either perspective alone. 
However there are some asymmetries in the findings. The findings suggest that international business is more important in moderating what are traditionally considered manufacturing choices than vice versa.

A number of themes emerge from the results:

1. Integrated plants locate on the basis of different location factors than independent plants. Integrated plant locations are more dependent on access to energy, raw materials, capital and local technology, perhaps because they can locate to take advantage of these inputs for the other plants in their companies. Contrary to expectations, access to low cost labor does not appear to be an important location determinant.

2. Distinctions between integrated and independent plants are more pronounced when the foreign or domestic context of these plants is considered. Different factors are important in different contexts.

3. Whereas integrated plants require both materials-flow and coordination, breaking independent plants into stand-alone, materials-flow only, and coordination only plants highlights differences in the importance of key suppliers and other plants for the location choice as well as some differences in access to factors of production.

4. Foreign plants locate on the basis of different national or regional characteristics, and domestic plants do not consider these factors. More importantly, access to factors of production is not an important discriminant between foreign and domestic plants.

5. The distinctions between foreign and domestic plant location determinants are generally unchanged when the manufacturing context is considered.

6. In general, when plant location determinants are ranked by importance, the most important determinants tend to be those that reflect how firms manage their multiple plant networks such as proximity to important customers and suppliers. National and regional characteristics such as regional trade barriers, government subsidies, and exchange rate risk are the least important determinants for locating both domestic and foreign plants. This result suggests that research which emphasizes that managers coordinate and locate plants to manage flexibility for government subsidies, exchange rate risk, and tax conditions is focusing on relatively unimportant determinants.

One limitation of the findings is that the strategic roles of plants may change over time. A plant may have been started as an independent plant but through the years turned into an integrated one. Our location determinants are based on the original plant location rationale while the responses used to categorize plants into independent and integrated plants are based on current characteristics of plants. If the strategic role has changed from independent to integrated over time, then we may be associating historic location determinants with changed plant types. Thus our model assumes that plants located to be independent or integrated plants do not routinely change role over time.

The contribution of the paper is that it combines manufacturing and international business perspectives to explain a critical decision in multinational firms - the plant location decision. The reason these perspectives are generally not combined for plant location analysis is that they tend to be associated with two different levels of analysis. The focus of much of international management research is on the relationship between business units and the corporate headquarters and less on plant management issues. The focus of manufacturing management research is on plant management issues and less on the context of those plants within the business unit or corporation. The combined perspectives yield some new results which suggest that more research is merited on the interdependence of choices involving manufacturing and international issues. ${ }^{1}$

\footnotetext{
${ }^{1}$ Financial support was provided in the Summer of 1996 by the Center for the Management of Manufacturing Enterprises of Purdue University. The data for this study came from a survey conducted by Brian Talbot and Aneel Karnani at the University of Michigan, and we are grateful to them for the use of the survey results. We would also like to thank Anil Khurana, Clayton Hubner, and Joan Penner-Hahn who worked on the survey instrument and helped to create the database. We are also very grateful to three anonymous reviewers.
} 


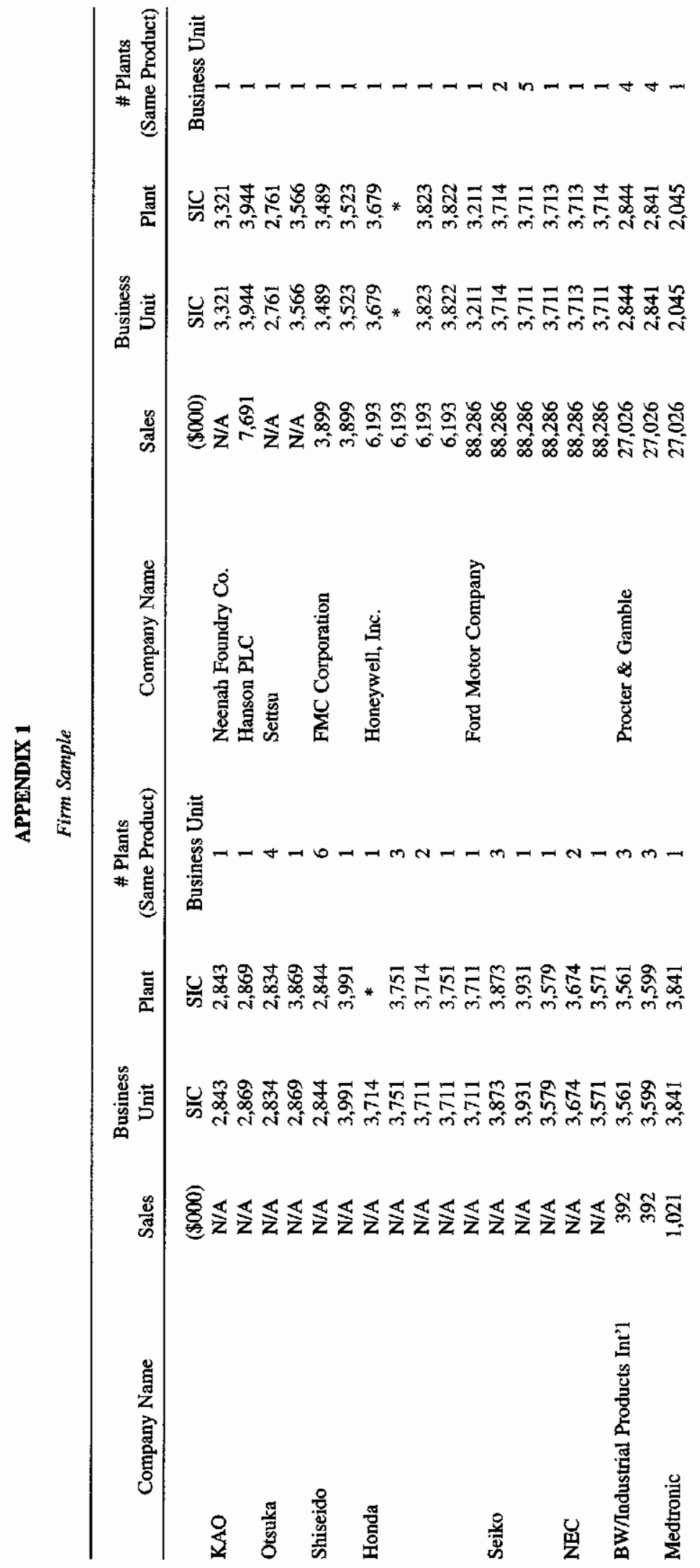




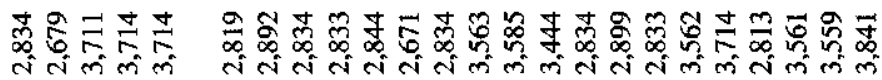

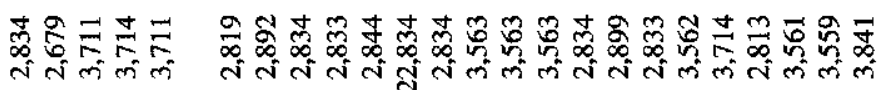

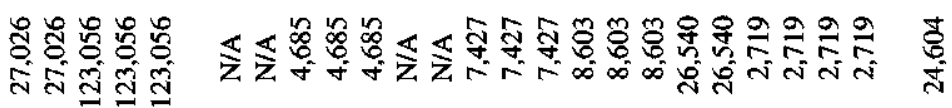

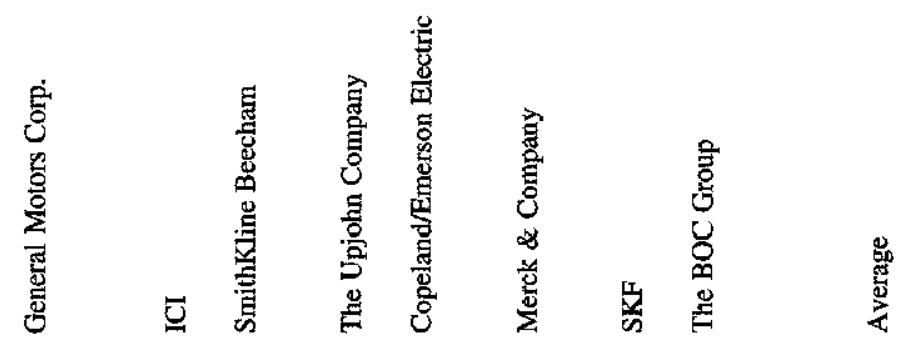

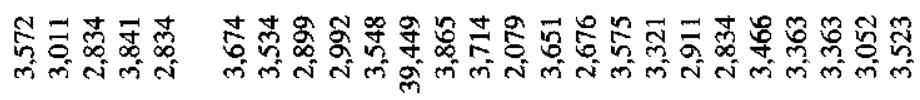

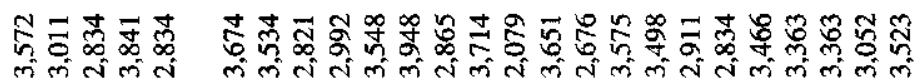

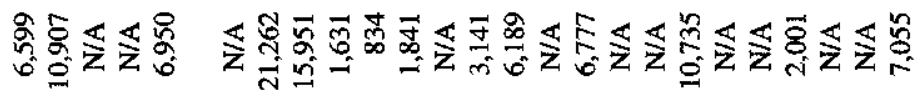

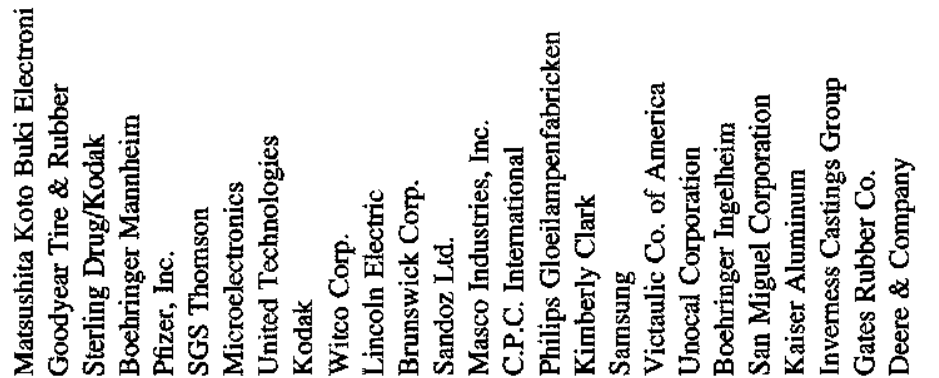




\section{TABLE APPENDIX 2}

Survey Questions

\section{Plant Location Determinants}

The next two questions deal with how different factors influence plant location decisions and plant effectiveness. The first question takes an historical perspective, while the second question looks at the situation today.

1. To what degree did the following factors influence your plant's location decision? (For each factor choose a number from zero to five, with 0 being not at all, 1 being very little extent, 2 being little extent, 3 being some extent, 4 being large extent, and five being very large extent).
a) proximity to important markets
b) proximity to key customers
c) proximity to key suppliers
d) proximity to other facilities belonging to business unit
e) access to raw materials
f) access to low-cost labor
g) access to skilled labor
h) access to energy
i) access to capital
j) access to local technology

k) access to protected markets

1) tax conditions

m) regional trade barriers

n) government subsidies

o) language/culture/politics

p) presence of advanced infrastructure (transportat'n, communicat'n, educat'n)

q) labor practices/regulation

r) environmental (pollution) regulation

s) exchange rate risk

2. Since your plant was built, conditions may have changed. Please indicate how the following factors would today influence the plant location decision? (Use above choices from 0 to 5 ).

\section{Materials Flows}

3. Which of the following best describes the materials flows among the plants in your business unit?
a)_ From central plants to satellite plants
d)_ from upstream to downstream plants
b)_. From satellite plants to central plants
c)_ between sister plants making similar products
e)_ all plants are stand-alone plants with minimal material flows between plants

\section{Coordination}

4. To what extent do the following factors contribute to achieving coordination/integration of manufacturing operations across plants in your business unit? (For each factor choose a number from zero to five, with 0 being not at all, 1 being very little extent, 2 being little extent, 3 being some extent, 4 being large extent, and five being very large extent).
a) product standardization
g) central sourcing
b) process standardization
h) central production planning
c) technology transfer from business unit headquarters/central R\&D
d) technology transfer across plants in your business unit
e) joint sourcing with other plants
f) joint production planning with other plants
j) interaction between managers/engineers across plants
i) common quality standards across all plants
k) interaction between plant-level and business unit headquarters personnel
1) similar cost account systems

\section{References}

Bartmess, A. D. (1994), "The Plant Location Puzzle," Harvard Business Review, 72, 2, 20-23. AND K. CERNY (1993), "Building Competitive Advantage Through a Global Network of Capabilities," California Management Review, 35, 2, 78-103.

Ben-Akiva, M. ANd S. R. LeRMan (1985), Discrete Choice Analysis, The MIT Press, Cambridge, MA.

CAvEs, R. (1982), Multinational Enterprise and Economic Analysis, Cambridge University Press, Cambridge, MA.

De MEYeR, A. AND A. VereEcke (1994), Strategies for International Manufacturing, Insead Working Paper Series, Fontainebleau, France.

DunNING, J. H. (1988), "The Eclectic Paradigm of International Production: A Restatement and Some Possible Extensions," Journal of International Business Studies, 19, 1-25.

- (1993), The Globalization of Business, Routledge, London, UK. 
FERDOws, K. (1989), "Mapping International Factory Networks"' in Managing International Manufacturing, K. Ferdows (ed.), Elsevier Science Publishers, B.V., North Holland, Amsterdam, 3-21.

Flaherty, T. (1986), "Coordinating International Manufacturing and Technology" in Competition in Global Industries, M. Porter (ed.), Harvard Business School Press, Boston, MA, 83-109.

GREENE, W. H. (1986), LIMDEP: User's Manual, New York University, New York.

GuPTA, A. AND V. GovindaRAJAN (1991), "Knowledge Flows and the Structure of Control Within Multinational Corporations,' Academy of Management Review, 16, 4, 768-792.

HAIGH, R. (1990), "Selecting a US Plant Location: The Management Decision Process in Foreign Companies," Columbia Journal of World Business, 25, Fall Issue, 22-31.

Hayes, R. and G. Pisano (1994), "Beyond World Class,'” Harvard Business Review, 72, 1, 77 -84.

HODDER, J. (1984), "'Financial Market Approaches to Facility Location Under Uncertainty," Operations Research, 32, 6, 1375-1380.

Huchzermeier, A. AND M. CoHen (1996), "Valuing Operational Flexibility Under Exchange Rate Risk," Operations Research, 44, 1, 100-113.

JUCKER, J. AND R. CARLSON (1976), “The Simple Plant-Location Problem Under Uncertainty," Operations Research, 24, 6, 1045-1055.

Kogut, B. (1985), ' 'Designing Global Strategies: Profiting from Operational Flexibility,' Sloan Management Review, Fall Issue, 27-38.

(1989), "Research Notes and Communications: A Note on Global Strategies," Strategic Management Journal, 10, 383-389.

AND N. KulatilaKa (1994), “Operating Flexibility, Global Manufacturing, and the Option Value of a Multinational Network,” Management Science, 40, 1, 124-139.

MacCormack, A. D., L. J. Newman III, AND D. B. Rosenfeld (1994), "The New Dynamics of Global Manufacturing Site Location,”' Sloan Management Review, 35, Summer Issue, 69-80.

NoHRIA, N. AND S. GHoshal ( 1994), "Differentiated Fit and Shared Values: Alternatives for Managing Headquarters-Subsidiary Relations,' Strategic Management Journal, 15, 6, 491-502.

OlIFF, M., J. ARPAN, AND F. Dubols (1989), "Global Manufacturing Rationalization: The Design and Management of International Factory Networks" in Managing International Manufacturing, K. Ferdows (ed.), Elsevier Science Publishers, B. V., North Holland, Amsterdam, 41-65.

Porter, M. (1985), Competitive Advantage, The Free Press, New York. (1990), The Competitive Advantage of Nations, The Free Press, New York.

Prahalad, C. AND Y. Doz (1987), The Multinational Mission: Balancing Local Demands and Global Vision, The Free Press, New York.

SAS (1990), SAS/STAT User's Guide, Volume 1, Version 6, Fourth Edition, SAS Institute, Inc., Cary, NC.

SCHMENNER, R., J. Huber, AND R. Cook (1987), "Geographic Differences and the Location of New Manufacturing Facilities," Journal of Urban Economics, 21, 1, 83-104.

(1979), "Look Beyond the Obvious in Plant Location," Harvard Business Review, 59, 1, JanuaryFebruary, 126-132.

(1982), "Multiplant Manufacturing Strategies among the Fortune 500," Journal of Operations Management, 2, 2, 77-86.

Upton, D. (1995), “What Really Makes Factories Flexible?," Harvard Business Review, 73, 4, pp. 74-79.

Von HiPPEL, E. A. (1978), "Users as Innovators," Technology Review, 80, 3, 3-11.

Thomas H. Brush is an Assistant Professor of Strategic Management at Purdue University. He earned a B.A. (in Economics) from Harvard College and a Ph.D. (in Economics and Business Administration) at University of Michigan. His research in corporate strategy focuses on resource sharing in acquisitions, diversified firm entry into new industries, and the relative size of the corporate business unit and industry effect in firm performance. These papers have been published in Strategic Management Journal. He has also published in the area of manufacturing strategy. Paper topics include the productivity effects of focused factories in Management Science, economic history and technical change in Explorations in Economic History, and the importance of service capabilities in veterinary medicine in Strategic Management Journal. He is a member of the Academy of Management and Strategic Management Society and is on the editorial board of the Strategic Management Journal.

Catherine A. Maritan is a Visiting Assistant Professor of Strategic Management at Purdue University. She earned a B.Sc. in Mining Engineering from Queen's University and M.S. and Ph.D. degrees in Management from Purdue University. Her research interests include capital investment decision processes, development of organizational capabilities, and manufacturing strategy. Prior to pursuing graduate studies, she worked as a mining engineer and a corporate banker.

Aneel Karnani is Associate Professor of Corporate Strategy and International Business at the University of Michigan Business School. He has held visiting appointments at the Northwestern University, London Business School, the Kiel Institute of World Economics (Germany), INSEAD (France), HEC (France), Helsinki School of Business Administration, Bocconi (Italy), Indian In- 
stitute of Foreign Trade, Chulalongkorn University (Thailand), INCAE (Costa Rica), and the National University of Singapore. In addition, he has lectured in several other countries in Latin America, Europe, and Asia. His teaching and research interests include competitive strategy, global competition, and manufacturing strategy. His publications include articles in professional journals such as Management Science, Strategic Management Journal, Academy of Management Proceedings, Decision Sciences, Marketing Science, and Omega, and several cases on strategic planning. He is a member of the editorial boards of the Strategic Management Journal, Management Decision, and Journal of Asian Business. 